\title{
Methane flux, vertical gradient and mixing ratio measurements in a tropical forest
}

\author{
C. A. S. Querino ${ }^{1,2}$, C. J. P. P. Smeets ${ }^{1}$, I. Vigano ${ }^{1}$, R. Holzinger ${ }^{1}$, V. Moura ${ }^{3}$, L. V. Gatti ${ }^{4}$, A. Martinewski ${ }^{4}$, \\ A. O. Manzi ${ }^{3}$, A. C. de Araújo ${ }^{3,5}$, and T. Röckmann ${ }^{1}$ \\ ${ }^{1}$ Institute for Marine and Atmospheric Research Utrecht, Utrecht University, Princetonplein 5, 3584 CC, Utrecht, \\ The Netherlands \\ ${ }^{2}$ Universidade Federal do Amazonas (UFAM), Instituto de Educação, Agricultura e Ambiente (IEAA), Campus Vale do Rio \\ Madeira, Rua 29 de Agosto, Centro, Humaitá - AM, Cep - 69800-000, Brazil \\ ${ }^{3}$ Instituto Nacional de Pesquisas da Amazônia (INPA), Large Scale Biosphere-Atmosphere Experiment in Amazonia (LBA), \\ Avenida André Araújo, 2936 - Aleixo, Manaus, CEP 69060-000, Brazil \\ ${ }^{4}$ Instituto de Pesquisa Energéticas e Nucleares (IPEN), Lab. Química Atmosférica (CQMA), Av. Prof. Lineu Prestes, 2242, \\ Cidade Universitaria, Sao Paulo - SP, CEP 05508-900, Brazil \\ ${ }^{5}$ Embrapa Amazônia Oriental, Tv. Dr. Enéas Pinheiro, s/n, Marco, Caixa postal 48, Belém, PA, CEP 66095-100, Brazil
}

Received: 21 January 2011 - Published in Atmos. Chem. Phys. Discuss.: 11 February 2011

Revised: 14 July 2011 - Accepted: 27 July 2011 - Published: 5 August 2011

\begin{abstract}
Measurements of $\mathrm{CH}_{4}$ mixing ratio, vertical gradients and turbulent fluxes were carried out in a tropical forest (Reserva Biológica Cuieiras), about $60 \mathrm{~km}$ north of Manaus, Brazil. The methane mixing ratio and flux measurements were performed at a height of $53 \mathrm{~m}$ (canopy height $35 \mathrm{~m}$ ). In addition, vertical $\mathrm{CH}_{4}$ gradients were measured within the canopy using custom made air samplers at levels of 2,16 and $36 \mathrm{~m}$ above ground. The methane gradients within the canopy reveal that there is a continuous methane source at the surface. No clear evidence for aerobic methane emission from the canopy was found. The methane fluxes above the canopy are small but consistently upwards with a maximum early in the morning. The measured fluxes are in agreement with the observed $\mathrm{CH}_{4}$ gradient in the canopy. In the morning hours, a strong canopy venting peak is observed for both $\mathrm{CH}_{4}$ and $\mathrm{CO}_{2}$, but for $\mathrm{CO}_{2}$ this peak is then superimposed by photosynthetic uptake, whereas the peak lasts longer for $\mathrm{CH}_{4}$. Monthly averaged diurnal cycles of the $\mathrm{CH}_{4}$ mixing ratio show a decrease during daytime and increase during nighttime. The magnitude of the difference in $\mathrm{CH}_{4}$ mixing ratio between day and night gradually increases throughout the wet season. The fluxes required to explain the nighttime increase are in agreement with the nighttime fluxes measured above the canopy, which implies that the $\mathrm{CH}_{4}$ increase in the nighttime boundary layer originates from local sources.
\end{abstract}

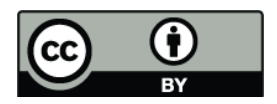

Correspondence to: C. A. S. Querino (c.querino@uu.nl)

\section{Introduction}

Amazonia plays a prominent role in the global carbon and methane cycle and its land use change implies numerous modifications to the biogeochemical cycles. Several studies have been carried out to understand the role of the tropical forest in the global cycle of the main greenhouse gases (Andreae et al., 2002; de Araújo et al., 2002; Bergamaschi et al., 2009; do Carmo et al., 2006; Janssens et al., 2001; Malhi et al., 1999; Malhi and Grace, 2000; Meirink et al., 2008; Miller et al., 2007; Molion, 1988; Sanhueza and Donoso, 2006).

Methane $\left(\mathrm{CH}_{4}\right)$ is the second most important anthropogenic greenhouse gas and its mixing ratio (presently $\sim 1.8 \mathrm{ppm}$ ) has increased by about $150 \%$ since pre-industrial times (Etheridge et al., 1998). It is the most predominant hydrocarbon and the most abundant organic trace gas in the Earth's atmosphere, with 25 times higher greenhouse warming potential than $\mathrm{CO}_{2}$ resulting in a $20 \%$ contribution to the current enhanced greenhouse effect (IPCC, 2007). $\mathrm{CH}_{4}$ also plays a central role in atmospheric oxidation chemistry and affects stratospheric ozone and water vapor levels (Lelieveld et al., 1998).

The atmospheric $\mathrm{CH}_{4}$ budget has been intensively studied over the past two decades using numerous techniques, including flux measurements (Bartlett and Harriss, 1993; Singh et al., 1997; Hendriks et al., 2008; Smeets et al., 2009), mixing ratio measurements in global monitoring networks (Dlugokencky et al., 1998, 2009), isotope measurements (Quay et al., 1999; Miller et al., 2002), forward inverse modeling

Published by Copernicus Publications on behalf of the European Geosciences Union. 
(Bousquet et al., 2006; Meirink et al., 2008; Bergamaschi et al., 2009) and recently also satellite remote sensing (Frankenberg et al., 2005, 2008).

Production of $\mathrm{CH}_{4}$ is generally believed to occur mainly in anoxic environments, such as the submerged soils of wetlands, paddy fields and rice fields, by methanogenic bacteria during the anaerobic degradation of organic matter, and gastrointestinal tract of ruminants (Itoh et al., 2009). In the tropics, $\mathrm{CH}_{4}$ is emitted at high rates from wetlands (Bartlett and Harriss, 1993), and conversion of forest-to-pasture may transform the soils from $\mathrm{CH}_{4}$ sinks to sources (Steudler et al., 1996). However, regional net emissions are poorly constrained.

The responses of methane emission to climate change or to forest clearing and associated agricultural development, land abandonment and ecological succession are still inadequately understood (Keller and Matson, 1994; Veldkamp et al., 1998). Megonigal and Guenther (2008) reviewed the available literature and found that the understanding of methane emissions from upland soil and vegetation was incomplete based on the few available measurements.

Using the first available global satellite dataset from SCIAMACHY, Frankenberg et al. (2005) concluded that current emission inventories considerably underestimate the magnitude of methane source in tropical areas. With improved spectroscopic parameters Frankenberg et al. (2008) noticed that the strong elevations of methane mixing ratios above the tropical rainforest regions reported in Frankenberg et al. (2005) could not be confirmed, but the data still imply a large source of $\mathrm{CH}_{4}$ in tropical areas (Bergamaschi et al., 2009).

do Carmo et al. (2006) used closed chamber and vertical profile measurements at three forests sites in Amazonia, to estimate an annual $\mathrm{CH}_{4}$ flux between 4 and $38 \mathrm{Tg} \mathrm{yr}^{-1}$, which even the lowest value already represents $1 \%$ of the total global $\mathrm{CH}_{4}$ emissions. They also concluded that there is no clear difference between wet and dry seasons. Other experiments conducted in a tropical savanna, suggest that this type of vegetation is a large source of $\mathrm{CH}_{4}$ with higher production during the dry than wet season (Crutzen et al., 2006; Sanhueza and Donoso, 2006). Miller et al. (2007) analyzed ground-based and airborne profiles measurements from 2000 to 2006 and found large methane emissions from the Amazon basin. They calculate emissions averaging $20 \mathrm{mg} \mathrm{CH}_{4}$ $\mathrm{m}^{-2}$ day $^{-1}$ from the area around Manaus.

As the underlying processes that produce $\mathrm{CH}_{4}$ in the tropics are still not well-quantified, the goal of this study was to learn about the $\mathrm{CH}_{4}$ budget on a local scale by in-situ measurements at a tropical forest site. We performed detailed measurements of $\mathrm{CH}_{4}$ fluxes, vertical gradients and mixing ratios in the Amazonia forest during the period of the international measurement campaign BARCA (Balanço Atmosférico Regional de Carbono na Amazônia) in Manaus - Amazonia.

\section{Methodology}

\subsection{Site description}

The Amazonia rainforest is well known for its diverse fauna and flora and peculiar characteristics in topography (Prance, 2001). We carried out experiments at the Reserva Biológica do Cuieiras, a terra firme forest covering an area of 22735 ha located about $60 \mathrm{~km}$ north of Manaus. The area is characterized by little deforestation, a canopy height around $35 \mathrm{~m}$ and mainly consists of vast expanses of undisturbed rainforest (de Araújo et al., 2002). The area consists of plateaus ( $\sim 40 \%)$ and valleys $(\sim 60 \%)$ with maximum height differences of about $60 \mathrm{~m}$. Measurements were done on a $53 \mathrm{~m}$ tall scaffolding flux tower called K34 (Fig. 1), which was erected in 1999. It is a $1.5 \times 2.5 \mathrm{~m}^{2}$ cross section aluminum tower that is located on a medium sized plateau $\left(2^{\circ} 36^{\prime} 32.67^{\prime \prime} \mathrm{S}\right.$, $60^{\circ} 12^{\prime} 33.48^{\prime \prime} \mathrm{W}, 130 \mathrm{~m}$ a.s.l.) (de Araújo et al., 2002). For a topographic image of the area and the exact location of the site we refer to Fig. 2 in de Araújo et al. (2010). The site belongs to the Instituto Nacional de Pesquisas da Amazonia (INPA), and it is coordinated by the Large Scale Biosphere and Atmospheric Experiment in Amazonian - LBA project. A detailed description of the site can be found in de Araújo et al. (2002).

The topography of valleys and plateaus implies that a plateau is surrounded by a vast area with lowlandwaterlogged vegetation. From plateau to valley the soil clay fraction decreases while the sand fraction increases. The valley soil is usually waterlogged during the rainy season (Chambers et al., 2004; Luizão et al., 2004), while plateau areas are characterized by well drained clay soils (de Araújo et al., 2002).

At plateau regions the microbial biomass in the first $20 \mathrm{~cm}$ of the soil layer varies from 266 to $1460 \mu \mathrm{gC} \mathrm{g}^{-1}$, which corresponds to 1.8 to $4.8 \%$ of the total soil carbon. The turnover time of soil microbes is 0.13 to $0.17 \mathrm{yr}$ (Andreae et al., 2002).

\subsection{Flux measurements}

Flux instruments were installed on the K34 tower (Fig. 1). The instrumentation consisted of a Fast Methane Analyzer (FMA, Los Gatos Research), a sonic anemometer (Campbell CSAT3), a Campbell FW3 Type E thermocouple and a LICOR LI7500 open-path fast $\mathrm{CO}_{2} \& \mathrm{H}_{2} \mathrm{O}$ analyzer. Raw data were sampled at $10 \mathrm{~Hz}$ using a Campbell CR1000 data logger and stored on a memory card. The FMA was operated in a closed-path eddy covariance (EC) set-up that carries the air through an $11 \mathrm{~m}$ long PVC tube $(1 \mathrm{~cm}$ inner diameter). The air inlet was located $53 \mathrm{~m}$ above the ground and $\sim 20 \mathrm{~m}$ above the canopy. The tube inlet was shielded from rain by a funnel that was mounted $0.2 \mathrm{~m}$ behind the sonic anemometer and close to the LI7500. Measurements were carried out between November 2008 and July 2009. Due to some technical 


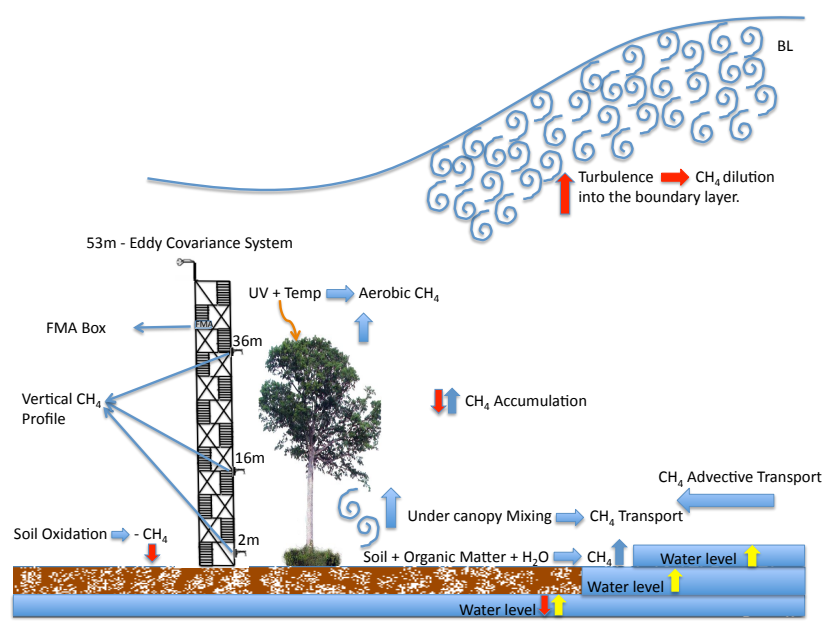

Fig. 1. Schematic picture of the measurement equipment installed at the $\mathrm{K} 34$ tower, in combination with processes that influence $\mathrm{CH}_{4}$ levels below and above the canopy in the tropical forest environment. 06:00 $\mathrm{h}$ integrated samples are taken at levels, near the ground $(2 \mathrm{~m})$, close to the top of the canopy $(36 \mathrm{~m})$ and in the middle of the canopy $(16 \mathrm{~m})$. The eddy flux equipment, including the inlet to the closed path FMA, is installed at $53 \mathrm{~m}$. $\mathrm{CH}_{4}$ is formed via anaerobic decomposition of the organic matter by methanogenic bacteria in the soil, which depends strongly on soil water level. Dynamical factors also should be considered. Under canopy mixing and advection can transport $\mathrm{CH}_{4}$ below the canopy. Since methane chemistry is rather slow, processes above the canopy is largely controlled by variations in the height of the planetary boundary layer, and by advection.

problem with the equipment, all the data from December, March and April had to be deleted.

Data processing was done in the same way as described in Smeets et al. (2009). Throughout this work we use the flux sign convention, i.e. positive flux values indicate an upward flux (from the canopy to the atmosphere), and negative values indicate a downward flux (from the atmosphere to the canopy). Details on data analysis are given in Appendices A and B. Most important was the correction of the WPLeffect (see Appendix A), which required the combination of the closed path data from the FMA and the open path $\mathrm{H}_{2} \mathrm{O}$ data. The delay time between the raw data signal from the anemometer and the open and close path sensors were determined to correct for the longitudinal separation of sensors as well as the tube delay (2 s). As in Ibrom et al. (2007) we also found a large difference in delay time between water vapor and other scalars that strongly varied with relative humidity. In Appendix A we describe all applied corrections in detail. In addition, a correction for the recently discovered $\mathrm{H}_{2} \mathrm{O}$ interference due to pressure broadening (Tuzson et al., 2010) was implemented. In Appendix B the detection limit for our $\mathrm{CH}_{4}$ flux measurements is discussed.

\subsection{Gradient and mixing ratio measurements}

Vertical $\mathrm{CH}_{4}$ mixing ratio gradients were measured during November and December 2008 using custom-made air samplers at 3 different levels $2 \mathrm{~m}, 16 \mathrm{~m}$ and $36 \mathrm{~m}$ (Fig. 2). Air was sampled at a constant flow rate of $11 \mathrm{ml} \mathrm{min}^{-1}$ over a period of $6 \mathrm{~h}$ by a metal bellows pump model MB-118E, and collected in 21 volume stainless steel canisters. The long time sampling was chosen to eliminate the short-term variability of methane mixing ratios due to turbulent mixing in the forest canopy. The canisters were changed up to four times per day. All canisters were pre-evacuated in the laboratory utilizing a high vacuum pump (TMH071P, Pfeiffer, Germany) before installation in the field. The samples were analyzed at the Atmospheric Chemistry Laboratory (LQA) of the Instituto de Pesquisas Energéticas e Nucleares (IPEN), São Paulo, Brazil, using the MAGICC (Multiple Analyses of Gases Influence Climate Change) system developed by NOAA/GMD. Precision and accuracy have been described in Miller et al. (2007).

\subsection{Calibration of the online measurements by flask samples}

For a limited period (April-July 2009) we collected once a week air samples for $\mathrm{CH}_{4}$ analysis at the top of the tower (50 m) next to the continuous $\mathrm{CH}_{4}$ flux and mixing ratio measurements of the FMA system (see above). These samples were collected using another custom-made air-sampling unit. The sampling unit filled two 11 glass flasks in about $5 \mathrm{~min}$ with ambient air to an absolute pressure of up to 1.9 bar using a KNF Neuberger pump type PM22874-86. Moisture was removed using DRIERITE ${ }^{\mathrm{TM}}$ with moisture indicator, which was replaced when it was $75 \%$ purple. The flask samples were analyzed in the IPEN laboratory, which allowed linking the FMA measurements to the international NOAA $2004 \mathrm{CH}_{4}$ scale (Dlugokencky et al., 2005). An average offset of $-36 \pm 9 \mathrm{ppb}$ between the FMA data and the flask data was established. We corrected the FMA data assuming that this offset was constant throughout the campaign.

\subsection{Rainfall and soil moisture measurements}

In order to characterize the climatology during the experimental period and its relation to $\mathrm{CH}_{4}$ production or absorption, soil moisture and rainfall data were analyzed. These data were obtained at the K34 automated weather station. Precipitation was collected using a rain gauge EM ARG100, Campbell Scientific. The total precipitation values were stored every $30 \mathrm{~min}$ in a Campbell CR10X data logger. Soil moisture was sampled every $30 \mathrm{~s}$ using a Profile Probe type PR1, Delta-T Devices Ltd. The measurements were made at six different depth levels $(0.05,0.1,0.2,0.3,0.5$ and $1 \mathrm{~m})$ and 10 min averages were stored in a Campbell Scientific CR10X data logger. 


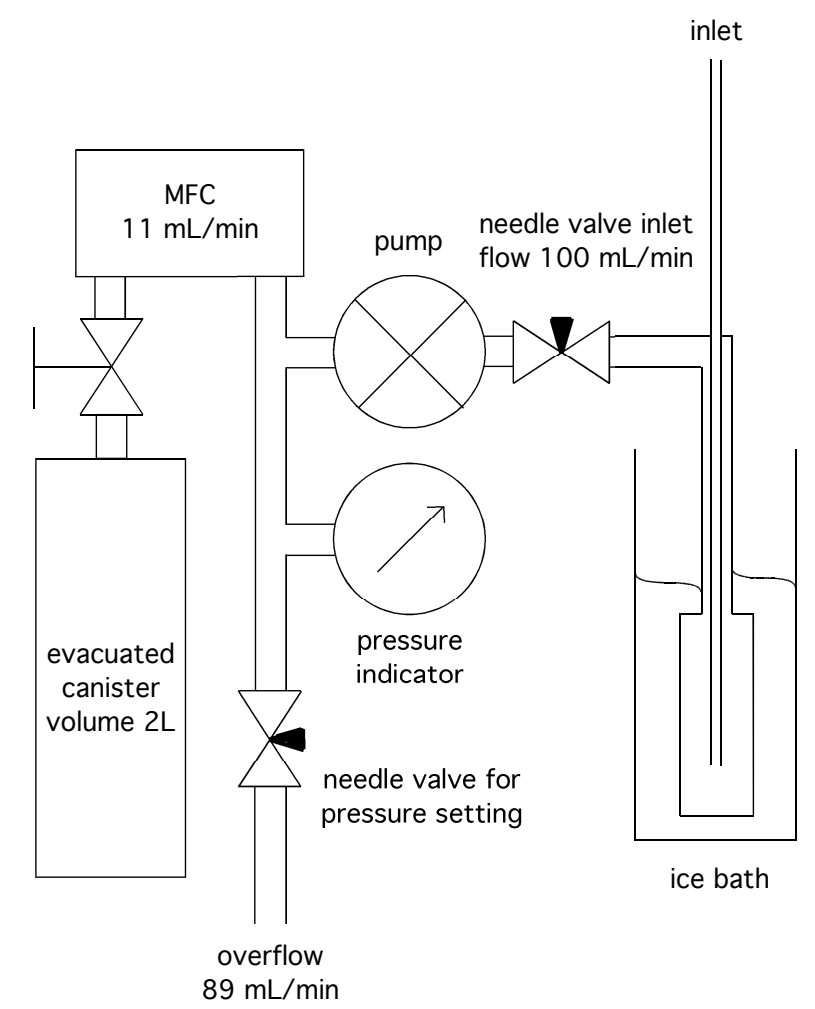

Fig. 2. Schematic drawing of the gradient air sampling units. Before filling the evacuated 21 sample canister, the air passes through an ice bath to reduce the humidity. The sample flow is set to $11 \mathrm{ml} \mathrm{min}^{-1}$ by a Mass Flow Controller (MFC). Typically samples were taken over a period of 06:00 $\mathrm{h}$.

The Climatological Normal $(\mathrm{CN})$ average yearly rainfall at the site is $2400 \mathrm{~mm}$ with two marked seasons (NovemberMay wet; June-October dry). Although highly variable, rainfall is present throughout the year, but typically less than $100 \mathrm{~mm}$ of precipitation occur from July to August (Chambers et al., 2004; de Araújo et al., 2008; Luizão et al., 2004). A comparison between the monthly rainfall in 2008/2009 and the $\mathrm{CN}$ is shown in Fig. 3. The study period (November 2008 to July 2009) showed some clear deviations from the $\mathrm{CN}$. The months before the experiment (dry season) had precipitation higher than the $\mathrm{CN}$. In particular, the first months of the measurement period (November to January) were unusually wet. The subsequent months (February, March and April), that usually mark the peak of the rain season, had slightly lower precipitation than the $\mathrm{CN}$ by about $30 \mathrm{~mm}$. At the beginning of the dry period, June and July had $140 \mathrm{~mm}$ and $60 \mathrm{~mm}$ more rain than the $\mathrm{CN}$. For the entire experiment period (November 2008-July 2009) precipitation surpasses the normal climatological mean by $523 \mathrm{~mm}$.

The soil moisture for six different depths throughout the experimental period is shown in Fig. 4. The three top levels $(0.01,0.05$ and $0.1 \mathrm{~m})$ were directly influenced by the rainfall increase. The most significant increase happened 2 months

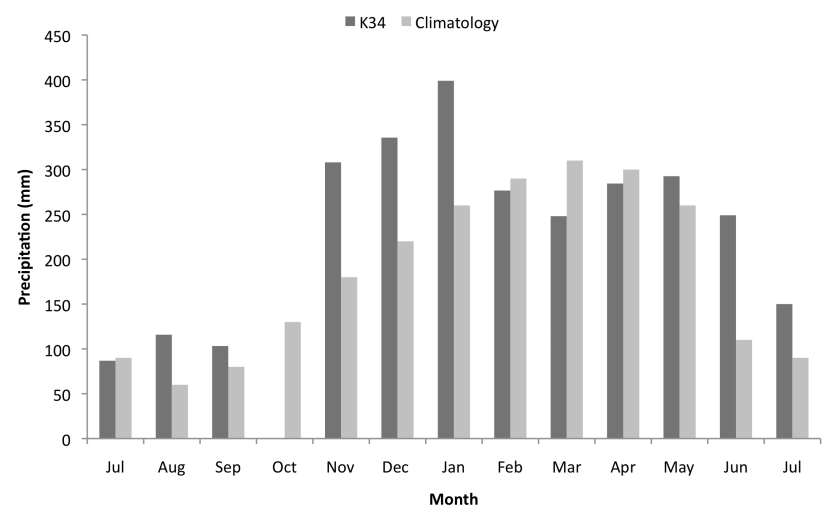

Fig. 3. Comparison between K34 rainfall data from July 2008 to July 2009 and the Manaus climatologically mean. Due to technical problems the data of October 2008 are not available.

after the rainy season starts (January). After January, the soil moisture only increases very slightly. The deeper levels show very small variability in soil moisture, with almost constant levels of $0.33,0.27$ and $0.42 \mathrm{~m}^{-3} \mathrm{~m}^{-3}$ at $0.3,0.5$ and $1 \mathrm{~m}$ respectively.

\section{Results}

\subsection{Vertical gradients}

An intensive campaign to measure vertical $\mathrm{CH}_{4}$ mixing ratio gradients in the canopy was carried out in NovemberDecember of 2008. Figure 5a and $\mathrm{b}$ show the raw $6 \mathrm{~h}$ average gradient data sampled during daytime (sampling started between 05:00 a.m. and 03:30 p.m. local time) and nighttime (sampling started after 04:00 p.m. and before 04:00 a.m.), respectively. The data show a large variability, and the mixing ratios below the canopy vary by $50 \mathrm{ppb}$. However, the changes within individual vertical gradients are much smaller and more systematic.

To obtain a better comparison of the $\mathrm{CH}_{4}$ mixing ratio profiles we removed the offset between the different profiles by calculating the difference between the 2nd level $(16 \mathrm{~m})$ and the ground level $(2 \mathrm{~m})$ and between the $3 \mathrm{rd}$ level $(36 \mathrm{~m})$ and ground level. The results are shown in Fig. $5 \mathrm{c}$ and d with the average differences printed in red. During daytime, the $\mathrm{CH}_{4}$ mixing ratio decreases $\sim 3.2 \mathrm{ppb}$ between the $2 \mathrm{~m}$ and the $16 \mathrm{~m}$ level, and $\sim 4.3 \mathrm{ppb}$ between $2 \mathrm{~m}$ and $36 \mathrm{~m}$. During nighttime, the difference between the first two levels is $\sim 3.4 \mathrm{ppb}$, and the difference increases to $9 \mathrm{ppb}$ between the 3rd and 1st level.

\subsection{Flux data}

Figure 6 shows the monthly averaged diurnal cycle of $\mathrm{CH}_{4}$ and $\mathrm{CO}_{2}$ vertical eddy fluxes over the measurement period. The $\mathrm{CH}_{4}$ fluxes are small, but measurable and reproducible 


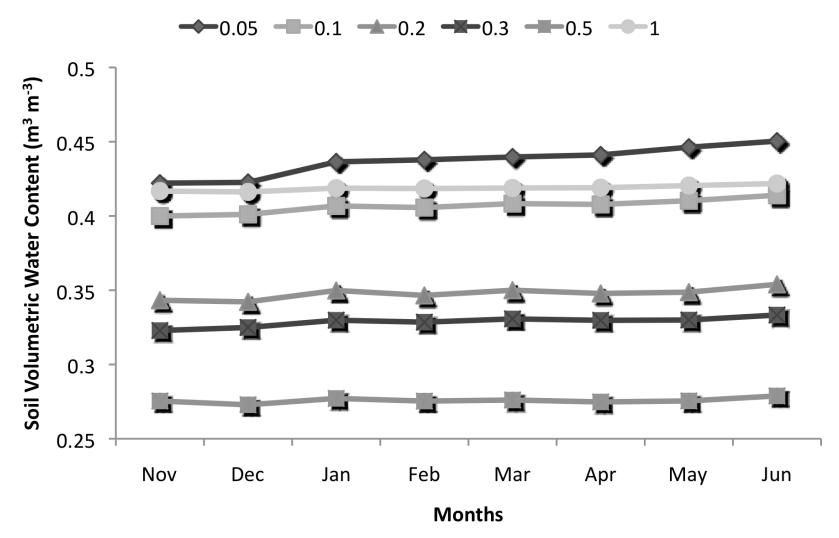

Fig. 4. Monthly average of the soil volumetric water content at six different levels below the surface (in meters) from November 2008 to June 2009.

between the months. Each morning after sunrise a peak in the $\mathrm{CH}_{4}$ fluxes is observed above the canopy (Fig. 6a). A similar peak is observed for the $\mathrm{CO}_{2}$ fluxes (Fig. 6b) although the duration of the peak is shorter, and in the case of $\mathrm{CO}_{2}$ it is followed by an extended period of negative fluxes. During the afternoon and throughout the night the $\mathrm{CH}_{4}$ fluxes are low, but on average positive, with values between 0.5 and $1.6 \mathrm{nmol} \mathrm{m} \mathrm{m}^{-2} \mathrm{~s}^{-1}$. The size of the morning peak appears to increase from the dry season month November (maximum flux $2 \mathrm{nmol} \mathrm{m}^{-2} \mathrm{~s}^{-1}$ ) to the wet season months, January, February and May (maximum flux $4-10 \mathrm{nmol} \mathrm{m}^{-2} \mathrm{~s}^{-1}$ ). The positive morning peak is the most prominent and significant feature in the $\mathrm{CH}_{4}$ flux data.

\subsection{Diurnal variability of $\mathrm{CH}_{4}$ mixing ratio}

To study the diurnal evolution and its variation throughout the season, the average diurnal $\mathrm{CH}_{4}$ mixing ratio cycle was calculated from the FMA data for each month (Fig. 7). Except for November 2008 all months clearly show a diurnal variation. Generally we observe a decrease during daytime and increase during nighttime. The diurnal amplitude increases from the beginning of the wet season (10 ppb in January) throughout the wet season to $>30 \mathrm{ppb}$ in the dry season (July). It should be noted that for the study region the timing of sunset and sunrise does hardly change throughout the year. The maximum nocturnal mixing ratios of $\mathrm{CH}_{4}$ are observed in July, while November exhibited the lowest values.

\section{Discussion}

\subsection{Vertical gradients}

Absolute $\mathrm{CH}_{4}$ mixing ratios varied from below 1790 to above $1840 \mathrm{ppb}$, and differences up to $\pm 40 \mathrm{ppb}$ were seen in subsequent sample sets separated by $6 \mathrm{~h}$. This is much more than the rather small vertical gradients shown in Fig. 5. It should be noted that it is not individual sample flasks that show these elevations, but all three samples from a certain vertical gradient, which strongly argues against contamination of individual flasks. Although our sampling resolution over a day is limited, it appears that episodes of $\mathrm{CH}_{4}$ elevations are not confined to a certain period of the day. This suggests that such episodes are not caused by local sources, but by advection of $\mathrm{CH}_{4}$-rich air. Tóta et al. (2008) detected a nocturnal subcanopy horizontal advection at K34 that transports a significant amount of $\mathrm{CO}_{2}$, which is a significant term in the local budgets. It is clear that in order to further examine this feature for $\mathrm{CH}_{4}$, high temporal resolution measurements are required. A continuous vertical gradient system is presently being installed at the K34 site. Such measurements should also reveal whether the observed negative vertical gradients (on average) can be observed year-round and whether the occasionally observed positive gradients are a robust feature and indeed occur regularly during daytime. A longer observation period is important since the vertical profile measurements presented here were limited to few weeks only ( 8 December- 9 January). These measurements describe a snapshot only, and we do not know whether the vertical gradients vary on longer timescales, and how they vary spatially between the plateaus to the valleys.

The decrease of $\mathrm{CH}_{4}$ mixing ratios with height inside the canopy implies that the surface on the plateau is a net source of methane in the measurement period, i.e. methane production surpasses methane uptake. The observed gradient is in agreement with measurement carried out on the ground. Soil flux chamber measurements have been initiated to investigate seasonality and spatial heterogeneity of these emissions, with the goal to link them to the gradient observations. First results (not shown here) indicate that the natural soil indeed produces $\mathrm{CH}_{4}$, but when the litter and surface soil layer are removed, methane can be taken up by the soil.

The present data add to the growing evidence that upland forests (i.e. not only wetlands) in Amazonia have to be considered a significant methane source. A positive surface flux was also determined by do Carmo et al. (2006) from measurements in a Brazilian forest. In contrast, for dry tropical forest soils in India, Singh et al. (1997) found that uptake dominated over production. The influence of water and temperature on the competition between $\mathrm{CH}_{4}$ uptake and production has been investigated by Itoh et al. (2009). They also observed $\mathrm{CH}_{4}$ production at values of soil water content and temperature comparable to the conditions at our measurement site.

Recent measurements have indicated that UV irradiation can lead to $\mathrm{CH}_{4}$ production from organic matter (McLeod et al., 2008; Vigano et al., 2008). In the tropical forest, the soil does not receive much radiation due to shielding from the canopy. Radiation is strong at the top of the canopy itself, but it was already argued that living plants should be well protected against UV radiation (Vigano et al., 2008). In 


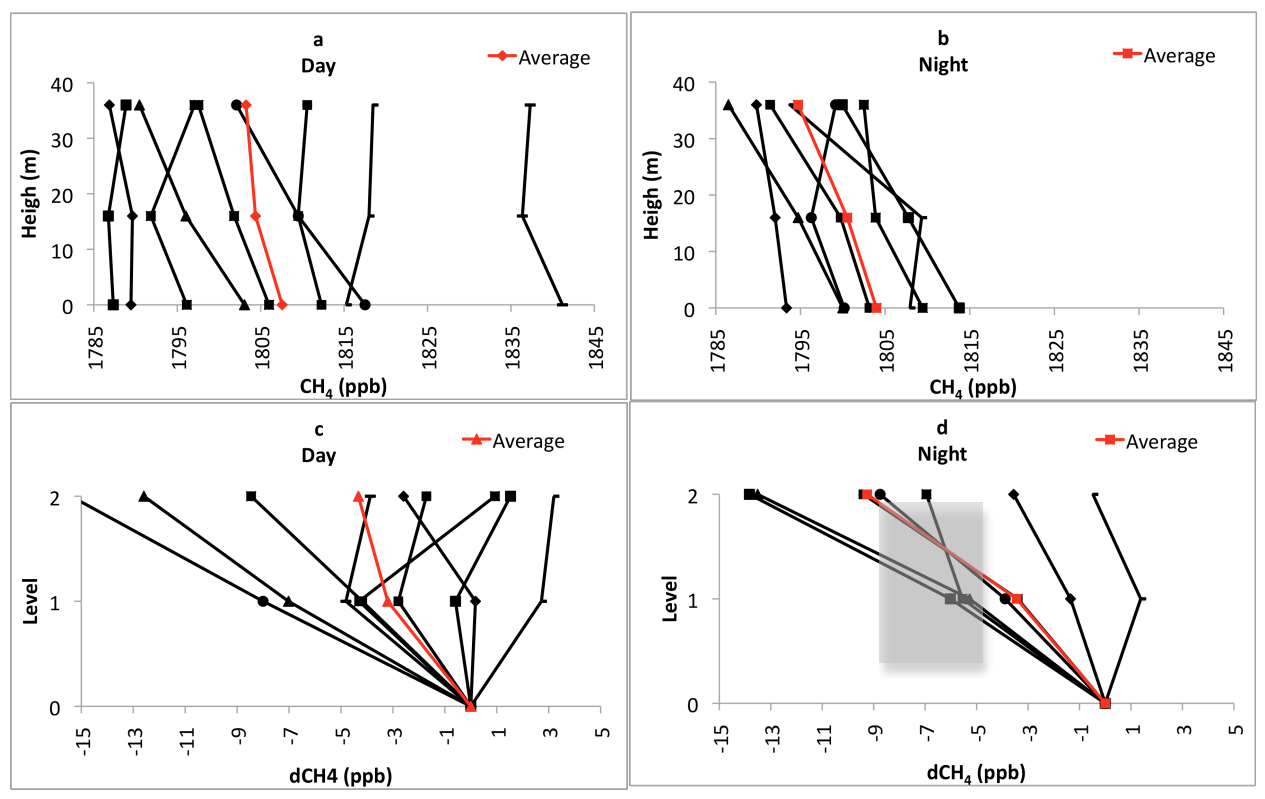

Fig. 5. Daytime and nighttime vertical gradient measurements. Panels (a) and (b) show $\mathrm{CH}_{4}$ mixing ratios. Panels (c) and (d) show the relative difference $\left(\mathrm{dCH}_{4}\right)$ between $36 \mathrm{~m}$ (level 2) and $16 \mathrm{~m}$ (level1) to the $2 \mathrm{~m}$ (level 0). The grey-shaded area in (d) corresponds to the average $\mathrm{CH}_{4}$ excess that is exchanged per hour from the canopy according to the calculations in Sect. 4.3.

our observations, the $\mathrm{CH}_{4}$ mixing ratio gradient is stronger between 2 and $16 \mathrm{~m}$ than between 16 and $36 \mathrm{~m}$. This does not suggest a significant $\mathrm{CH}_{4}$ production in the canopy. Tóta et al. (2008) studied sub-canopy horizontal and vertical $\mathrm{CO}_{2}$ fluxes. Results showed that nighttime advection could transport significant amounts of $\mathrm{CO}_{2}$ in the lowest $10 \mathrm{~m}$ of the canopy. According to the same research advection accounted for $73 \%$ and $71 \%$ of the $\mathrm{CO}_{2}$ budget during the dry and wet period. Advection could have similar relevance for $\mathrm{CH}_{4}$. Nevertheless, if $\mathrm{CH}_{4}$ is horizontally transported below the canopy, it also implies that production is happening close to the ground.

\subsection{Turbulent fluxes above the canopy}

The main feature of the eddy flux data is the clear flux peak in the morning. Coinciding with sunrise at 06:00 a.m. local time, the measured fluxes start increasing and reach a mean level of almost $6 \mathrm{nmolm}^{-2} \mathrm{~s}^{-1}$ for $\mathrm{CH}_{4}$ and $\sim 9 \mu \mathrm{mol} \mathrm{m}{ }^{-2} \mathrm{~s}^{-1}$ for $\mathrm{CO}_{2}$ between 7 and 08:00 a.m. local time. de Araújo et al. (2002), observed a similar $\mathrm{CO}_{2}$ peak at this flux tower. They interpreted it as a canopy venting peak, where $\mathrm{CO}_{2}$ from respiration, that has accumulated inside the canopy at night, is transported upward into the boundary layer in the morning. Accumulation occurs due to radiative cooling at the top of the canopy leading to stably stratified air that acts as a lid on top of the canopy (Tóta et al., 2008). In the case of $\mathrm{CO}_{2}$, the venting peak is quickly superimposed by the strong $\mathrm{CO}_{2}$ uptake signal due to photosynthesis. Our $\mathrm{CH}_{4}$ flux data show that methane is not affected by such a compensating process. This suggests that methane measurements allow inferring the real duration of the canopy venting period, and averaged over all months the peak has a width of about $5 \mathrm{~h}$. After $\sim 12: 00$ p.m., the fluxes return to the low positive value around $0.5-1.6 \mathrm{nmol} \mathrm{m}^{-2} \mathrm{~s}^{-1}$ that continues throughout the rest of the day. The $\mathrm{CO}_{2}$ fluxes remain clearly negative until sunset ( $\sim 06: 00$ p.m. local time), as was observed by de Araújo et al. (2002) and Culf et al. (1997).

Apart from this strong flux peak, it is notable that the fluxes of $\mathrm{CH}_{4}$ are small but positive throughout the day. During the night, this also holds for $\mathrm{CO}_{2}$. It is known that application of the eddy flux technique is limited to periods in which turbulent mixing dominates. At night, surface cooling suppresses turbulent transport and increases horizontal advection possibly leading to an underestimate of emissions during calm and clear nights (Goulden et al., 2006). However, for $\mathrm{CH}_{4}$, the nighttime fluxes are very similar to the fluxes measured during the afternoon, where conditions for eddy-flux measurements are more favorable. In Appendix B, we show detailed covariance spectra for the nighttime fluxes and calculated a detection limit, which implies that the small values are significantly different from zero.

The positive $\mathrm{CH}_{4}$ gradients measured inside the canopy discussed above (Sect. 4.1 and Fig. 5) provide further support for the positive fluxes detected above the canopy throughout the day. A detailed study of the vertical dispersion of trace gas at another Amazon rainforest station in Rondonia (Simon et al., 2005) showed canopy flushing rates of one hour at $90 \%$ canopy height. We note that the canopy at the 

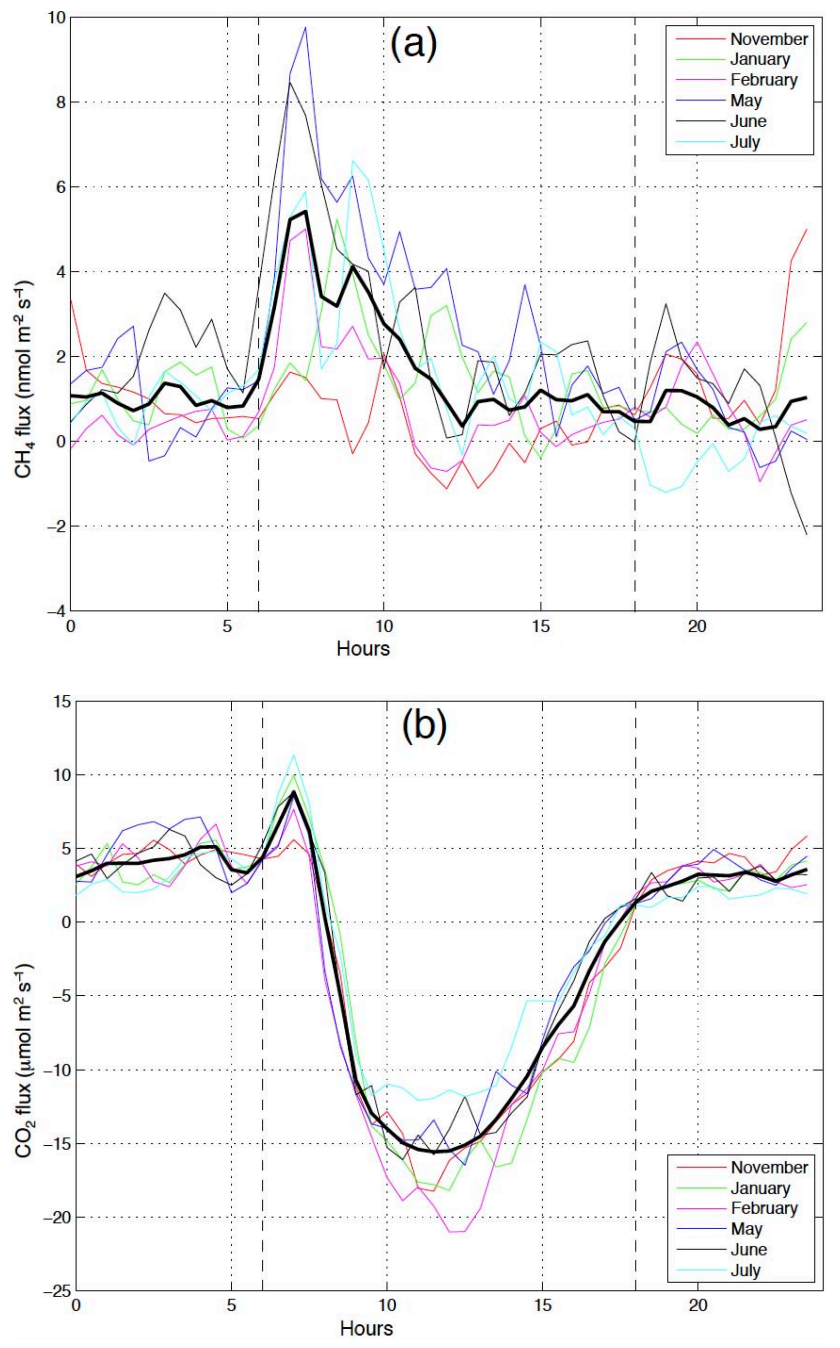

Fig. 6. Monthly averaged diurnal cycles of $\mathrm{CH}_{4}$ (a) and $\mathrm{CO}_{2}$ (b) fluxes measured at the top of the K34 tower.

Rondonia site is higher ( $43 \mathrm{~m}$ ) than at K34, and the canopy and turbulence statistics may be different at the two sites. Nevertheless, in the absence of similar data for our location, we use this flushing rate for a rough estimate. From the gradient results in Fig. 5, we estimate that a $\mathrm{CH}_{4}$ excess of $\sim 5 \mathrm{ppb} \cdot 30 \mathrm{~m}^{3}$ is emitted from the canopy per $\mathrm{m}^{2}$ and per hour, which corresponds to a $\mathrm{CH}_{4}$ flux of $40 \mathrm{~nL} \mathrm{~m}^{-2} \mathrm{~s}^{-1}$ or $1.6 \mathrm{nmol} \mathrm{m}^{-2} \mathrm{~s}^{-1}$. This value is similar to the nighttime fluxes $\left(\sim 1 \mathrm{nmol} \mathrm{m}^{-2} \mathrm{~s}^{-1}\right)$ measured during the same period (November), and thus provides independent support for positive $\mathrm{CH}_{4}$ fluxes during day and night. These two independent datasets provide an internally consistent picture and the $\mathrm{CH}_{4}$ flux detected above the canopy can be explained by local production at the surface.

It is useful to compare the total average measured flux of $\sim 2$ nmole $\mathrm{m}^{-2} \mathrm{~s}^{-1}$, which corresponds to $\sim 2.8 \mathrm{mg} \mathrm{CH}_{4} \mathrm{~m}^{-2}$ day $^{-1}$ to the flux estimates from Miller et al. (2007), who deduced an average flux of $20 \mathrm{mg} \mathrm{CH}_{4} \mathrm{~m}^{-2}$ day $^{-1}$ from air-

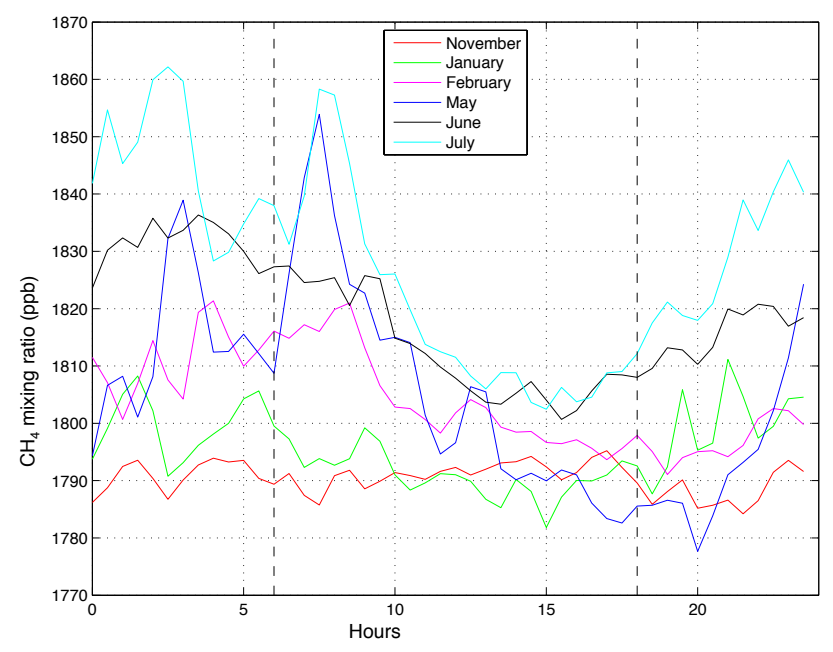

Fig. 7. Monthly averaged diurnal cycles of $\mathrm{CH}_{4}$ mixing ratios measured with the FMA at the top of the tower K34 during six months. Vertical dashed lines indicate the time of sunrise and sunset, respectively.

craft flights in the Manaus Amazon basin. It follows that the measured emissions from the upland forest reported here are probably not representative for the Amazon basin as the fluxes are probably much higher in wetland areas (e.g. from the valleys). Multiplying $\sim 2.8 \mathrm{mg} \mathrm{CH}_{4} \mathrm{~m}^{-2}$ day $^{-1}$ by the total forest area in Amazonia of $5 \times 10^{6} \mathrm{~km}^{2}$ yields an estimate for the total annual $\mathrm{CH}_{4}$ flux of $5 \mathrm{Tg} \mathrm{yr}^{-1}$, which is about $1 \%$ of the total global $\mathrm{CH}_{4}$ emissions and similar to results reported by do Carmo et al. (2006), however, this a factor of 7 lower than the total flux calculated with the emission of $20 \mathrm{mg} \mathrm{CH}_{4} \mathrm{~m}^{-2}$ day $^{-1}$ from Miller et al. (2007).

\subsection{Diurnal variations above the canopy}

The measurements above the canopy (53 $\mathrm{m}$, top of the tower) revealed clear diurnal cycles in $\mathrm{CH}_{4}$ mixing ratio and the amplitude of these cycles varies throughout the season from almost no diurnal variability in November to $>30 \mathrm{ppb}$ in July. In general, $\mathrm{CH}_{4}$ mixing ratios above the canopy increase during night and decrease during the day. This shape of the diurnal cycle can be qualitatively explained by accumulation of surface emissions in the shallow nighttime stable boundary layer and dilution of the accumulated $\mathrm{CH}_{4}$ into the daytime planetary boundary layer when the nocturnal layer breaks up. This has been discussed in detail in Culf et al. (1997) for the case of $\mathrm{CO}_{2}$.

No information on the height of the nighttime boundary layer at the location of the K34 tower is available, but Culf et al. (1997) reported boundary layer heights around $100 \mathrm{~m}$ above the canopy during the Rondonia Boundary Layer Experiment. We can use this estimate for a back-ofthe-envelope calculation to estimate which flux is required to explain the observed nighttime increase in $\mathrm{CH}_{4}$ mixing 
ratio. At $1800 \mathrm{ppb}$, a total volume of $10^{5} 1$ above $1 \mathrm{~m}^{2}$ canopy surface contains $180 \mathrm{ml}$ or $7.2 \mathrm{mmol} \mathrm{CH}_{4}$. An increase of $0.1 \% \mathrm{~h}^{-1}\left(=1.8 \mathrm{ppbh}^{-1}\right)$ is then required to produce the observed average nighttime increase of roughly $20 \mathrm{ppb}$. If this flux was produced locally, we should thus observe a continuous nighttime flux of $7.2 \mu$ mole $\mathrm{m}^{-2} \mathrm{~h}^{-1}$, or 2 nmole $\mathrm{m}^{-2} \mathrm{~s}^{-1}$.

This is of the order of the observed mean nighttime flux between 0.5 and 4 nmole $\mathrm{m}^{-2} \mathrm{~s}^{-1}$ for the different months, and similar to the estimate based on the gradients and canopy mixing times as discussed above. Therefore the nighttime EC flux measured directly at the tower is sufficient to explain the increase in $\mathrm{CH}_{4}$ mixing ratios above the canopy during the night.

\section{Conclusions}

The collective evidence from vertical $\mathrm{CH}_{4}$ gradient measurements in an upland tropical forest, $\mathrm{CH}_{4}$ fluxes above the canopy, and the diurnal cycle of $\mathrm{CH}_{4}$ mixing ratio above the canopy, suggests that this ecosystem is a source of $\mathrm{CH}_{4}$ to the atmosphere. $\mathrm{CH}_{4}$ fluxes directly measured above the canopy are positive, and can explain the observed increase of methane mixing ratios in the boundary layer during the night. A canopy venting peak is observed for $\mathrm{CH}_{4}$ around sunrise. The total duration of elevated fluxes due to canopy venting is of order of five hours. Nevertheless, this flux is not detectable as a mixing ratio increase above the canopy, since mixing with free tropospheric air due to the breakup of the nighttime boundary layer overwhelms the small flux from the canopy. No conclusive evidence for aerobic methane emissions from the canopy could be found, although some individual vertical profiles showed an increase in $\mathrm{CH}_{4}$ mixing ratio from the middle to the top of the canopy, and the average decrease between these two levels is less during day than during night. Gradient measurements with higher temporal resolution and for a longer period will be required to address this issue in more detail. The present measurements indicate that the source of $\mathrm{CH}_{4}$ at this site is located at the ground. Together with advective transport close to the surface all our observations can be understood.

\section{Appendix A}

\section{The delay time of water vapor versus scalars in a closed-path system}

Scalars (e.g. $\mathrm{CH}_{4}$ mixing ratio) and water vapor can behave very differently inside the tube of a closed path system. As first shown quantitatively by Ibrom et al. (2007), the delay time of water vapor transport through a tube can be much larger than for other scalars and strongly depends on relative humidity. As a consequence, the water vapor dilution of scalars (i.e. the Webb Pearman Leuning - WPL effect) inside

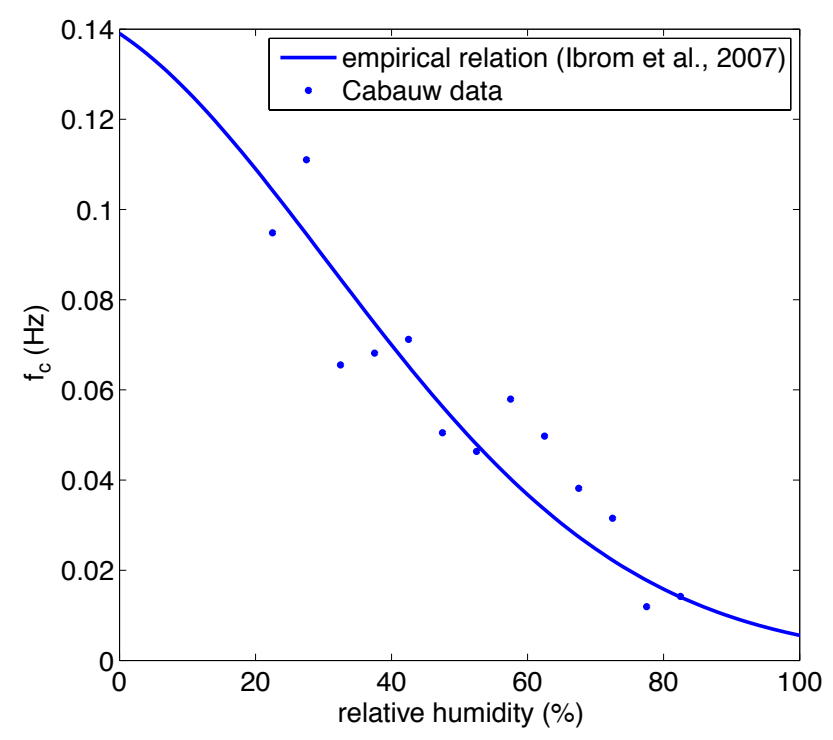

Fig. A1. Cut-off frequency for water vapor as a function of relative humidity. The symbols are the results from combining different fits to the spectra and various data selection criteria applied to the Cabauw data. The solid line represents the empirical model presented by Ibrom et al. (2007).

the closed-path system is desynchronized. Following Ibrom et al. (2007), the desynchronization of the water vapor signal can be simulated as the low pass filtering with a first-order recursive filter

$H(f)=\frac{1}{1+\left(f / f_{\mathrm{c}}\right)}$

where $f_{\mathrm{c}}$ is the cut-off frequency (the frequency at which the filter reduces the power spectral estimates by a factor of 2). Ibrom et al. (2007) present an exponential function that predicts the increase of $f_{\mathrm{c}}$ as a function of relative humidity for their EC-system. Moreover, they also demonstrate that the same relation can be used to other EC-systems with very different tube dimensions (i.e. radius and length). We confirm their findings by using measurements performed at the CESAR observatory near Cabauw, The Netherlands, (http://www.cesar-observatory.nl) at $20 \mathrm{~m}$ height during the summer of 2010. The measurement system that we used was the same as at the K34 tower in Manaus with the addition of a closed path LI-COR LI6262 $\mathrm{H}_{2} \mathrm{O} / \mathrm{CO}_{2}$ analyzer. The LI6262 and FMA were both connected to the same $20 \mathrm{~m}$ tube (the same as we use for the experiments at K34). The water vapor signal measured with the LI6262 is assumed to be the same as that within the measurement cell of the FMA. We used these data to calculate power spectra for the water vapor and fitted these to obtain values for the cut-off frequency. The results are plotted as a function of relative humidity in Fig. A1 together with the empirical model from Ibrom et al. (2007). 
Table A1. Values for the constants used in Eq. (A4).

\begin{tabular}{lcc}
\hline & $c_{1}\left(\mathrm{~m}^{-1}\right)$ & $c_{2}(\mathrm{~Hz})$ \\
\hline Unstable & $2.457 \times 10^{-3}$ & $6.342 \times 10^{-4}$ \\
Stable & $6.761 \times 10^{-3}$ & $2.906 \times 10^{-3}$ \\
\hline
\end{tabular}

Our data scatter around the empirical formula from Ibrom et al. (2007) and we decided to adopt their empirical model given as

$f_{\mathrm{c}}=e^{-2.499 \mathrm{RH}^{2}-0.717 \mathrm{RH}-1.973}$

where RH is the relative humidity. The calculation of the low pass filtering effect on the fluxes by means of a phase shift of water vapor inside the tube is performed as described in Ibrom et al. (2007)

$F=\frac{\overline{w^{\prime} C^{\prime}}}{\overline{w^{\prime} C^{\prime} m}}$

where $\overline{w^{\prime} C^{\prime}}$ and $\overline{w^{\prime} C^{\prime} m}$ is the actual flux in the atmosphere and the low pass filtered flux inside the closed path system, respectively. A model for $F$ can be described as

$F=\frac{c_{1} u}{c_{2}+f_{\mathrm{c}}}+1$

where the constants $c_{1}$ and $c_{2}$ are presented in Ibrom et al. (2007) separately for stable and unstable stratification (see Table A1).

\section{Appendix B}

\section{The validity of the nighttime $\mathrm{CH}_{4}$ fluxes}

For a correct estimate of the detection limit we estimated its maximum value via a trial and error method that repeatedly calculates covariance for a range of lag times between $w^{\prime}$ and $\mathrm{CH} / 4$, i.e. the vertical velocity component and the methane mixing ratio, respectively. The flux detection limit can be estimated as the standard deviation for a range of covariances calculated in a lag-time window far away from the lag time of maximum covariance (Wienhold et al., 1995; Kroon et al., 2007). We calculated covariance for a lag-time window ranging between plus and minus 80 to $100 \mathrm{~s}$. The standard deviation of the covariance within this range is an estimate for the lower detection limit of $\mathrm{CH}_{4}$ fluxes for one half-hour interval. Calculating the true detection limit for $\mathrm{CH}_{4}$ fluxes is however not straightforward since it includes the influence of water vapor fluxes via the WPL effect. We apply the same procedure as described in (Smeets et al., 2009) to obtain the true detection limit.

In Fig. B1 we display the averaged diurnal variation of methane fluxes and the corresponding detection limit for the

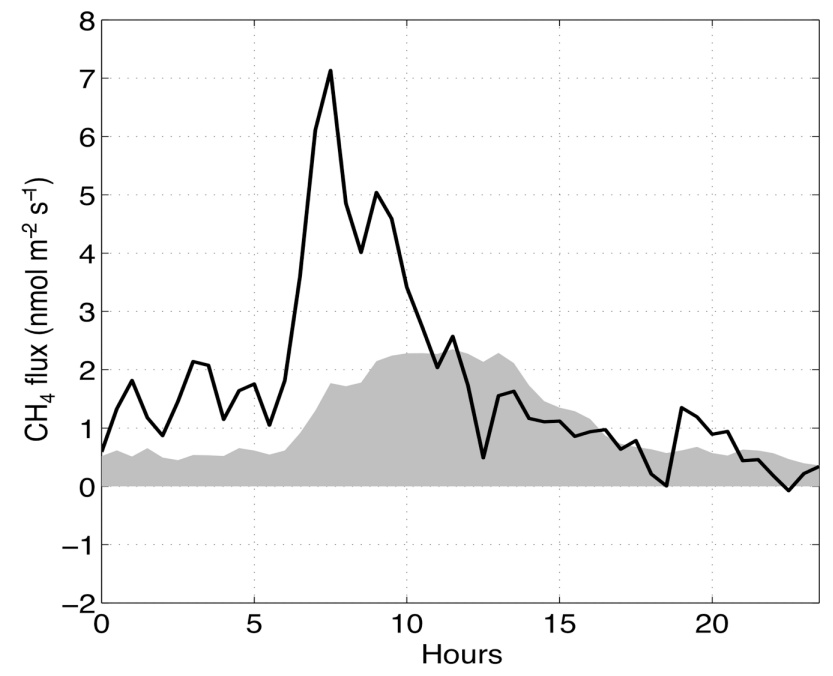

Fig. B1. Averaged diurnal variations of methane fluxes (solid line) and the corresponding detection limit (filled area) for data obtained from January to July 2009.

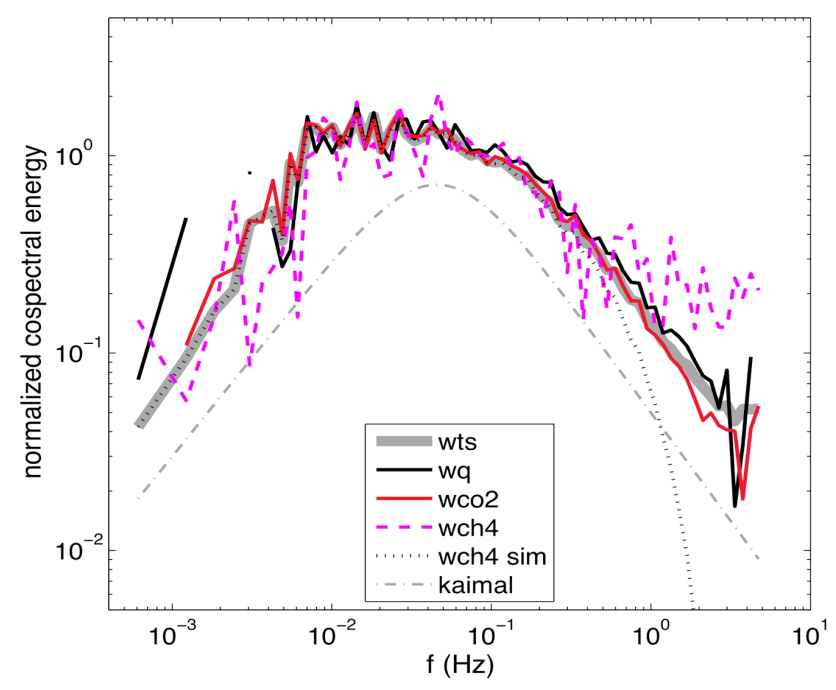

Fig. B2. Normalized averaged co-spectra from an ensemble of 109 half hour nighttime runs obtained between 20:00 $\mathrm{h}$ and 05:00 $\mathrm{h}$ from February to July 2009. The co-spectra for sonic temperature, water vapor, $\mathrm{CO}_{2}$ and $\mathrm{CH}_{4}$ flux are plotted as a function of natural frequency. The dotted black curve $\left(\mathrm{CH}_{4}\right.$ simulated) represents an estimate of the expected shape of the co-spectrum of $\mathrm{CH}_{4}$ without the influence of signal noise. The dashed grey curve is the arbitrarily offset near-neutral universal co-spectrum (Kaimal et al., 1972; Kaimal, 1973). The average stability and wind speed for the ensemble are $z / L=+0.65$ and $\bar{u}=2.2 \pm 0.6 \mathrm{~m} \mathrm{~s}^{-1}$.

whole measurement period. In particular in the second half of the night (after midnight), the measured fluxes are above the detection limit. These results illustrate that, although the methane fluxes measured become very small during the night, they are most of the time larger than the detection 
limit. Consequently, our results for continuous upward directed methane fluxes during the night are realistic.

The quality of our nighttime flux data (between 20:00 h and 05:00 h) is also illustrated by the average from an ensemble of 109 normalized co-spectra as a function of the natural frequency presented in Fig. B2. Note that we did not use the dimensionless frequency $\left(f_{z} / u\right)$ to average our co-spectra because the wind speed variations within the selection of 109 runs were small $\left(\bar{u}=2.2 \pm 0.6 \mathrm{~m} \mathrm{~s}^{-1}\right)$. The co-spectra of sensible heat and water vapor, $\mathrm{CO}_{2}\left(C_{w} T_{s}, C_{w q}\right.$ and $C_{w} \mathrm{CO}_{2}$ ) overlap and compare very well to the universal Kansas curve for near neutral co-spectra (Kaimal et al., 1972; Kaimal, 1973). The universal curve was arbitrarily offset so that a comparison with its slope at low and high frequencies is not obscured by our co-spectra. This result is another indication for the high quality of our EC measurements.

Acknowledgements. This work was funded by the Dutch NWO under grant number 865.07.001. Special thanks to all LBA/Manaus staff whose direct and indirect involvement gave us logistic support. As well as IMAU technicians (Michel Bolder, Carina van der Veen and Henk Snellen) involved on the experimental setup.

Edited by: J. Rinne

\section{References}

Andreae, M. O., Artaxo, P., Brandão, C., Carswell, F. E., Ciccioli, P., da Costa, A. L., Culf, A. D., Esteves, J. L., Gash, J. H. C., Grace, J., Kabat, P., Lelieveld, J., Malhi, Y., Manzi, A. O., Meixner, F. X., Nobre, A. D., Nobre, C., Ruivo, Md. L. P., Silva-Dias, M. A., Stefani, P., Valentini, R., von Jouanne, J., and Waterloo, M. J.: Biogeochemical cycling of carbon, water, energy, trace gases and aerosols in Amazonia: The LBA-EUSTACH experiments, J. Geophys. Res., 107, 8066, doi:10.1029/2001JD000524, 2002.

Bartlett, K. B. and Harriss, R. C.: Review and assessment of methane emissions from wetlands, Chemosphere, 26, 261-320, 1993.

Bergamaschi, P., Frankenberg, C., Meirink, J. F., Krol, M., Villani, M. G., Houweling, S., Dentener, F., Dlugokencky, E. J., Miller, J. B., Gatti, L. V., Engel, A., and Levin, I.: Inverse modeling of global and regional $\mathrm{CH} 4$ emissions using SCIAMACHY satellite retrievals, J. Geophys. Res., 114, D22301, doi:10.1029/2009JD012287, 2009.

Bousquet, P., Ciais, P., Miller, J. B., Dlugokencky, E. J., Hauglustaine, D. A., Prigent, C., Van der Werf, G. R., Peylin, P., Brunke, E. G., Carouge, C., Langenfelds, R. L., Lathiere, J., Papa, F., Ramonet, M., Schmidt, M., Steele, L. P., Tyler, S. C., and White, J.: Contribution of anthropogenic and natural sources to atmospheric methane variability, Nature, 443, 439-443, 2006.

Chambers, J. Q., Tribuzy, E. S., Toledo, L. C., Crispim, B. F., Higuchi, N., Santos, J. dos, de Araújo, A. C., Kruijt, B., Nobre, A. D., and Trumbore, S.: Respiration from a tropical forest ecosystem: partitioning of sources and low carbon use effi ciency, Ecol. Appl., 14(4), S72-S88, Supplement, 2004.

Culf, A. D., Fisch, G., Malhi, Y., and Nobre, C. A.: The influence of the atmospheric boundary layer on carbon dioxide concentra- tions over a tropical forest, Agr. Forest Meteorol., 85, 149-158, 1997.

Crutzen, P. J., Sanhueza, E., and Brenninkmeijer, C. A. M.: Methane production from mixed tropical savanna and forest vegetation in Venezuela, Atmos. Chem. Phys. Discuss., 6, 3093 3097, doi:10.5194/acpd-6-3093-2006, 2006.

de Araújo, A. C., Nobre, A. D., Kruijt, B., Elbers, J. A., Dallarosa, R., Stefani, P., von Randow, C., Manzi, A. O., Culf, A. D., Gash, J. H. C., Valentini, R., and Kabat, P.: Comparative measurements of carbon dioxide fluxes from two nearby towers in a central Amazonian rainforest: The Manaus LBA site, J. Geophys. Res., 107, 8090, doi:10.1029/2001JD000676, 2002.

de Araújo, A. C., Kruijt, B., Nobre, A. D., Dolman, A. J., Waterloo, M. J., Moors, E. J., and Souza, J. S.: Nocturnal accumulation of $\mathrm{CO}_{2}$ underneath a tropical forest canopy along a topographical gradient, Ecol. Appl., 18(6), 1406-1419, 2008.

de Araújo, A. C., Dolman, A. J., Waterloo, M. J., Gash, J. H. C., Kruijt, B., Zanchi, F. B., de Lange, J. M. E., Stoevelaar, R., Manzi, A. O., Nobre, A. D., Lootens, R. N., and Backer, J.: The spatial variability of $\mathrm{CO}_{2}$ storage and the interpretation of eddy covariance fluxes in central Amazonia, Agr. Forest Meteorol., 150, 226-237, 2010.

do Carmo, J. B., Keller, M, Dias, J. D., Camargo, P. B., and Crill, P.: A source of methane from upland forests in the Brazilian Amazon, Geophys. Res. Lett., 33, L04809, doi:10.1029/2005GL025436, 2006.

Dlugokencky, E. J., Masarie, K. A., Lang, P. M., and Tans, P. P.: Continuing decline in the growthrate of the atmospheric methane burden, Nature, 393, 447-450, 1998.

Dlugokencky, E. J., Myers, R. C., Lang, P. M., Masarie, K. A., Crotwell, A. M., Thoning, K. W., Hall, B. D., Elkins, J. W., and Steele, L. P.: Conversion of NOAA atmospheric dry air $\mathrm{CH} 4$ mole fractions to a gravimetrically prepared standard scale, J. Geophys. Res., 110, D18306, doi:10.1029/2005JD006035, 2005.

Dlugokencky, E. J., Bruhwiler, L., White, J. W. C., Emmons, L. K., Novelli, P. C., Montzka, S.A., Masarie, K. A., Lang, P. M., Crotwell, A. M., Miller, J. B., and Gatti, L. V.: Observational constraints on recent increases in the atmospheric $\mathrm{CH}_{4}$ burden, Geophys. Res. Lett., 36, L18803, doi:18810.11029/12009gl039780, 2009.

Etheridge, D. M., Steele, L. P., Francey, R. J., and Langenfields, R. L.: Atmospheric methane between 1000 A.D. and present: Evidence of anthropogenic emissions and climatic variability, J. Geophys. Res., 103, 15979-15993, 1998.

Frankenberg, C., Meirink, J. F., van Weele, M., Platt, U., and Wagner, T.: Assessing methane emissions from global space-borne observations, Science, 308(5724), 1010-1014, doi:10.1126/science.1106644, 2005.

Frankenberg, C., Bergamaschi, P., Butz, A., Houweling, S., Meirink, J. F., Notholt, J., Petersen, A. K., Schrijver, H., Warneke, T., and Alben, I.: Tropical methane emissions: A revised view from SCIAMACHY onboard ENVISAT, Geophys. Res. Lett., 35, L15811, doi:10.1029/2008GL034300, 2008.

Goulden, M. L., Miller, S. D., and da Rocha, H. R.: Nocturnal cold air drainage and pooling in a tropical forest, J. Geophys. Res., 11, D08S04, doi:10.1029/2005JD006037, 2006.

Hendriks, D. M. D., Dolman, A. J., van der Molen, M. K., and van Huissteden, J.: A compact and stable eddy covariance set-up for methane measurements using off-axis integrated 
cavity output spectroscopy, Atmos. Chem. Phys., 8, 431-443, doi:10.5194/acp-8-431-2008, 2008.

IPCC: Fourth Assessment Report, Climate Change, Cambridge University Press, Cambridge, 2007.

Itoh, M., Ohte, N., and Koba, K.: Methane flux characteristics in forest soils under an East Asian monsoon climate, Soil Biol. Biochem., 41(2), 388-395, 2009.

Ibrom, A., Dellwik, E., Flyvbjerg, H., Jensen, N. O., and Pilegaard, K.: Strong low-pass filtering effects on water vapour flux measurements with closed-path eddy correlation systems, Agr. Forest Meteorol., 147, 140-156, 2007.

Janssens, I. A., Kowalski, A. S., and Ceulemans, R.: Forest floor $\mathrm{CO} 2$ fluxes estimated by eddy covariance and chamber-based model, Agr. Forest Meteorol., 106, 61-69, 2001.

Kaimal, J. C.: Turbulence spectra, length scales and structure parameters in the stable surface layer, Boundary Layer Meteorol., 4, 289-309, 1973.

Kaimal, J. C., Wyngaard, J. C., Izumi, Y., and Cote, O. R.: Spectral characteristics of surface layer turbulence, Q. J. Roy. Meteorol. Soc., 98, 653-689, 1972.

Keller, M. and Matson, P. A.: Biosphere-atmosphere exchange of trace gases in the tropics, in: Evaluating the eff ect of land-use changes, in: Global Atmospheric, Biospheric Chemistry, edited by: Prinn, R. G., Biospheric Chemistry, Plenum, New York, 103117, 1994.

Kroon, P. S., Hensen, A., Jonker, H. J. J., Zahniser, M. S., van 't Veen, W. H., and Vermeulen, A. T.: Suitability of quantum cascade laser spectroscopy for $\mathrm{CH}_{4}$ and $\mathrm{N}_{2} \mathrm{O}$ eddy covariance flux measurements, Biogeosciences, 4, 715-728, doi:10.5194/bg-4715-2007, 2007.

Lelieveld, J., Crutzen, P. J., and Dentener, F. J.: Changing concentration, lifetimes and climate forcing of atmospheric methane, Tellus, 50, 128-150, 1998.

Luizão, R. C. C., Luizão, F. J., Paiva, R. Q., Monteiro, T. F., Sousa, L. S., and Kruijt, B.: Variation of carbon and nitrogen cycling processes along a topographic gradient in a Central Amazonian forest, Glob. Change Biol., 10(5), 592-600, doi:10.1111/j.15298817.2003.00757.x, 2004.

Malhi, Y. and Grace, J.: Tropical forests and atmospheric carbon dioxide, Trends Ecol. Evolut., 15, 332-337, 2000.

Malhi, Y., Baldocchi, D. D., and Jarvis, P. G.: The carbon balance of tropical, temperate and boreal forests, Plant Cell Environ., 22, 715-740, 1999.

McLeod, A. R., Fry, S. C., Loake, G. J., Messenger, D. J., Reay, D. S., Smith, K. A., and Yun, B. W.: Ultraviolet radiation drives methane emissions from terrestrial plant pectins, New Phytol., 180(1), 124-132, 2008.

Megonigal, J. P. and Guenther, A. B.: Methane emissions from upland forest soils and vegetation, Tree Physiol., 28, 491-498, 2008.

Meirink, J. F., Bergamaschi, P., Frankenberg, C., d'Amélio, M. T. S., Dlugokencky, E. J.,Gatti, L. V., Houweling, S., Miller, J. B., Röckmann, T., Villani, M. G., and Krol, M. C.: Four-dimensional variational data assimilation for inverse modeling of atmospheric methane emissions: Analysis of SCIAMACHY observations, J. Geophys. Res., 113, D17301, doi:17310.11029/12007JD009740, 2008.

Miller, J. B., Mack, K. A., Dissly, R., White, J. W. C., Dlugokencky, E. J., and Tans, P. P.: Development of analytical methods and measurements of $13 \mathrm{C} / 12 \mathrm{C}$ in atmospheric $\mathrm{CH}_{4}$ from the NOAA/CMDL global air sampling network, J. Geophys. Res., 107(D13), 4178, doi:10.1029/2001JD000630, 2002.

Miller, J. B., Gatti, L. V., d'Amélio, M. T. S., Crotwell, A. M., Dlugokencky, E. J., Bakwin, P., Artaxo, P., and Tans, P. P.: Airbone measurements indicate large methane emissions from the eastern Amazon basin, Geophys. Res. Lett., 34, L10809, doi:10.1029/2006GL029213, 2007.

Molion, L. C. B.: A Amazônia e o clima da Terra, Ciencia Hoje, 48(8), 42-47, 1988.

Prance, G.: Encyclopedia of Biodiversity, Academic Press, 1, 145157, 2001.

Quay, P., Stutsman, J., Wilbur, D., Snover, A., Dlugokencky, E., and Brown, T.: The isotopic composition of atmospheric methane, Global Biogeochem. Cy., 13, 445-461, 1999.

Sanhueza, E. and Donoso, L.: Methane emission from tropical savanna Trachypogon sp. grasses, Atmos. Chem. Phys., 6, 53155319, doi:10.5194/acp-6-5315-2006, 2006.

Simon E., Lehamann, B. E., Ammann, C., Ganzeveld, L., Rummel, U., Meixner, F. X., Nobre, A. D., de Araújo, A., and Kesselmeier, J.: Lagrangian dispersion of $222 \mathrm{Rn}, \mathrm{H}_{2} \mathrm{O}$ and $\mathrm{CO}_{2}$ within Amazonian rain forest, Agr. Forest Meteorol., 132, 286-304, 2005.

Singh, J. S., Singh, S., Raghubanshi, A. S., Singh, S., Kashyap, A. K., and Reddy, V. S.: Effects of soil nitrogen, carbon and moisture on methane uptake by dry tropical forest soils, Plant Soil, 196, 115-121, 1997.

Smeets, C. J. P. P., Holzinger, R., Vigano, I., Goldstein, A. H., and Röckmann, T.: Eddy covariance methane measurements at a Ponderosa pine plantation in California, Atmos. Chem. Phys., 9, 8365-8375, doi:10.5194/acp-9-8365-2009, 2009.

Steudler, P. A., Melillo, J. M., Feigl, B. J., Neill, C., Piccolo, M. C., and Cerri, C. C.: Consequence of forest-to-pasture conversion on $\mathrm{CH} 4$ fluxes in the Brazilian Amazon Basin, J. Geophys. Res., 101(18), 547-554, 1996.

Tóta, J., Fitzjarrald, D. R., Staebler, R. M., Sakai, R. K., Moraes, O. M. M., Acevedo, O. C., Wofsy, S. C., and Manzi, A. O.: Amazon rain forest subcanopy flow and the carbon budget: Santare'm LBA-ECO site, J. Geophys. Res.-Biogeo, 113(15), G00B02, doi:10.1029/2007JG000597, 2008.

Tuzson, B., Hiller, R. V., Zeyer, K., Eugster, W., Neftel, A., Ammann, C., and Emmenegger, L.: Field intercomparison of two optical analyzers for $\mathrm{CH}_{4}$ eddy covariance flux measurements, Atmos. Meas. Tech., 3, 1519-1531, doi:10.5194/amt-3-15192010, 2010.

Veldkamp, E., Keller, M., and Nunez, M.: Eff ects of pasture management on $\mathrm{N}_{2} \mathrm{O}$ and $\mathrm{NO}$ emissions from soils in the humid tropics of Costa Rica, Global Biogeochem. Cy., 12, 71-79, 1998.

Vigano, I., van Weelden, H., Holzinger, R., Keppler, F., McLeod, A., and Röckmann, T.: Effect of UV radiation and temperature on the emission of methane from plant biomass and structural components, Biogeosciences, 5, 937-947, doi:10.5194/bg5-937-2008, 2008.

Wienhold, F. G., Welling, M., and Harris, G. W.: Micrometeorological measurements and source region analysis of nitrous oxide fluxes from an agricultural soil, Atmos. Environ., 29(17), 22192227, 1995. 